\title{
What caused the great inflation moderation in the US? A post-Keynesian view
}

\author{
Nathan Perry* \\ Department of Business, Colorado Mesa University, Grand Junction, CO, USA \\ Nathaniel Cline* \\ Department of Economics, University of Redlands, CA, USA
}

Several explanations of the 'great inflation moderation' (1982-2006) have been put forth, the most popular being that inflation was tamed due to good monetary policy, good luck (exogenous shocks such as oil prices), or structural changes such as inventory management techniques. Drawing from post-Keynesian and structuralist theories of inflation, this paper uses a vector autoregression with a post-Keynesian identification strategy to show that the decline in the inflation rate and inflation volatility was due primarily to (i) wage declines and (ii) falling import prices caused by international competition and exchange-rate effects. The paper uses a graphical analysis, impulse response functions, and variance decompositions to support the argument that the decline in inflation has in fact been a wage and import price moderation. A Taylor rule differential variable was also used to test the 'good policy' hypothesis. The results show that the Taylor rule differential has a smaller effect on inflation, controlling for other factors.

Keywords: inflation, Taylor rule

JEL codes: $E 12, E 31$

\section{INTRODUCTION}

As inflation and output volatility declined after the 1970s, it became fashionable to declare an end to macroeconomic history. Lucas (2003) famously argued that the problems of 'depression-prevention' had been solved by efficient policy. History, however, has returned with a vengeance. As economists look backward for explanations for the present recession, the stylized facts of the so-called 'Great Moderation' take on a new importance. In particular, the dangerous deflation and disinflation that followed 2008 and the severe collapse in output and employment call into question the mainstream understanding of the relationships between macroeconomic structure, shocks, and policymaking during the Great Moderation.

The supposed end of macroeconomic history was associated with theoretical and practical developments in the conduct of monetary policy. After the inflationary episode of the 1970s, economists became convinced that central banking was best done independently from democratic politics. Central banks across the world and in developing countries, in particular, were encouraged to declare their independence and

* The authors would like to thank, without implicating, two anonymous referees of this journal. 
adopt technocratic policy rules that would provide credibility, stabilizing market expectations (Grabel 2003). The Great Moderation then was evidence of the success of these institutions.

Prior to 2008, in the midst of the moderation, many heterodox and post-Keynesian authors argued that stability was hiding structural imbalances that suggested an unsustainable aggregate demand regime. ${ }^{1}$ In addition, some, following a Minskyian (1986) line, argued that the moderation itself was partly responsible for the crisis, by encouraging greater leveraging (Keen 2013). Thus, household balance sheets and fragile financial structures have been at the center of heterodox and post-Keynesian descriptions of the crisis. In this view, central bank independence and rigid policy rules bear no direct responsibility for stability, and in fact may be detrimental (Arestis and Sawyer 2008).

The reduction in inflation that supposedly resulted from the new policy framework can, however, be explained along post-Keynesian and structuralist lines. While the consensus among mainstream macroeconomists suggests that the rate of inflation is a monetary phenomenon, the level of inflation in post-Keynesian thought has traditionally been related to distributional conflict (Lavoie 1992). Thus, postKeynesian pricing models tend to emphasize cost pressures and look to wage demands, commodity prices, import prices, and mark-ups to explain the Great Moderation in inflation.

This paper seeks to test the relevance of cost factors as opposed to changes in monetary policy during the period of inflation moderation. Using a vector autoregression (VAR) analysis, we test the contribution of wage pressures and import prices as compared to the 'good policy' hypothesis of some mainstream authors as represented by the Taylor rule. In addition, a competing hypothesis in the mainstream literature suggests that 'good luck,' potentially in the form of fewer oil shocks, may have meant that policy had an easier task during the Great Moderation. We suggest that oil prices may actually be endogenous to the system through exchange-rate effects. Our results confirm the importance of cost pressures and their interaction, and de-emphasize the role of policy rules.

The paper proceeds as follows: Section 2 provides a short summary of the basic features of the Great Moderation and the new consensus macroeconomics that emerged during this period. Section 3 discusses the post-Keynesian and structuralist view of inflation. Section 4 provides the details of the data and the importance of the relationships between variables that make this study unique. Sections 5 and 6 provide the model and results for a vector autoregression with an explicitly post-Keynesian ordering that tests for both cost push and 'good policy' factors. Section 7 concludes with suggestions for further exploration.

\section{THE INFLATION MODERATION AND THE NEW CONSENSUS MACROECONOMICS}

Most authors have dated the decline in inflation and price volatility to the early 1980s (see, for example, Stock and Watson 2003). This is confirmed in Table 1, which presents the standard deviations for compensation, output, unit labor costs, crude materials inflation, and consumer price index (CPI) inflation for the post-WWII period.

1. Among others, Godley (1999), Palley (2002), and Keen (2006). Bezemer (2009) discusses a selection of economists - many in the heterodox/post-Keynesian camp - who predicted a debtdeflation-style crisis. 
Table 1 Volatility of wage, productivity, and unit labor costs 1948-2006

\begin{tabular}{lcccc}
\hline & Compensation $^{\mathrm{b}}$ & Output per hour $^{\mathrm{b}}$ & Unit labor cost $^{\mathrm{b}}$ & Crude materials inflation \\
\hline 1948-2006 & 0.0073 & 0.0088 & 0.0111 & 0.0418 \\
$1948-1983$ & 0.0072 & 0.0100 & 0.0124 & 0.0331 \\
1984-2006 & 0.0064 & 0.0065 & 0.0081 & 0.0528 \\
Relative S.D. & 0.8965 & 0.6504 & 0.6563 & 1.5915 \\
\hline
\end{tabular}

Notes:

a. In the empirical model later in this paper, our preferred indicator is the employment cost index. Unit labor costs are used in this table because employment cost index data does not exist before 1977.

b. Indicates variables in growth rates.

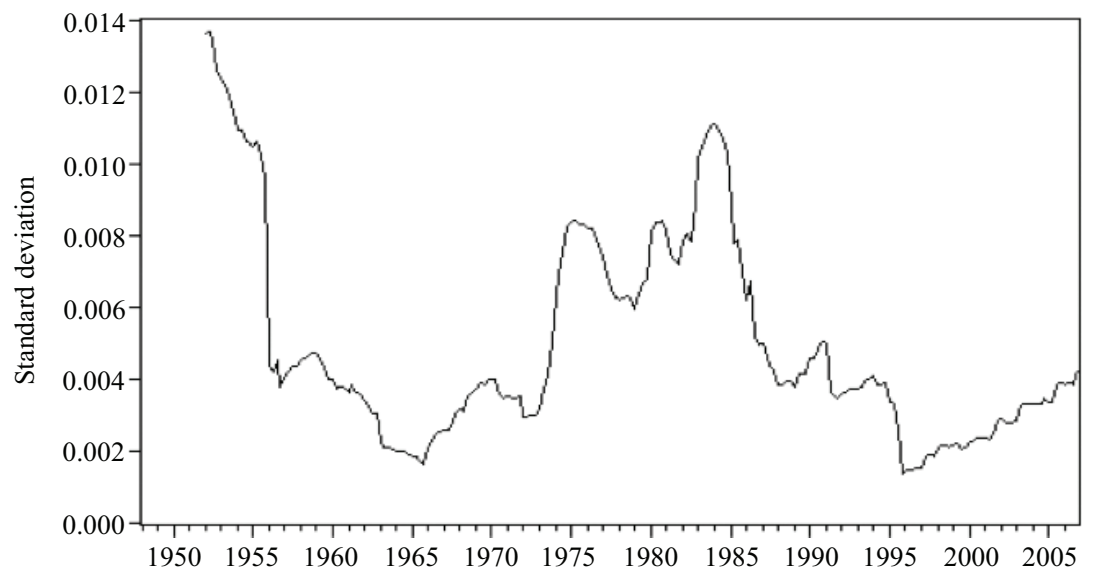

Figure 1 20-quarter rolling standard deviation of CPI inflation

Notably, volatility in CPI inflation was more than halved. Similarly, smaller declines in volatility can be seen in hourly compensation, output per hour, and unit labor costs. Interestingly, crude materials have actually increased in volatility, a feature in line with the commodities price boom of the 2000s, which followed nearly 2 decades of relatively depressed prices.

One can see the decline in the volatility of prices in Figure 1, which plots the rolling standard deviation of CPI inflation with a 20-quarter window. Here, the decline in volatility seems less abrupt than is implied by the 1983 break date in Table 1 . Indeed, a point of contention among macroeconomists has been whether to view the Great Moderation as a stark break, with some arguing that it should, rather, be seen as a declining trend in volatility (Blanchard and Simon 2001).

What is clear, however, is that after a particularly volatile period in the 1970 s, the rate and volatility of inflation declined steadily until at least the mid 2000s. This was roughly coincident with the decline in the volatility of other macroeconomic series, including output growth (Kim et al. 2003). The debate has thus focused on the causes of the moderation of macroeconomic data.

In general, explanations have been grouped into three camps: good policy, good luck, and structural changes. Good policy reflects the introduction of macroeconomic rules, particularly central-bank policy rules, which were supposed to bring 
transparency and credibility, which would in turn moderate inflation and output. Good luck reflects a host of factors, domestic and international, including but not limited to financialmarket shocks, commodity-price shocks, and technology shocks. The structural-change explanations have concentrated on information technology and other changes that make inventory management easier and less prone to mistakes.

A common thread amongst mainstream treatments of decline in inflation and its volatility is the firm belief that ultimately inflation is a monetary phenomenon. In this sense, no matter the specific causes, in the long run inflation is always and everywhere a result of money-supply expansion. That is, without an accommodating monetary policy, persistent inflation is not possible. The implication is thus that inflation has its origins in excess demand.

The method by which monetary changes affect prices has, since Friedman (1968), operated through an output (or unemployment) and inflation trade-off. Behind these models lie the 'natural' rates of interest and unemployment. As in Wicksell (1898), when the market rate of interest is equal to the natural rate, inflation will be constant, output will be at capacity, and unemployment at its natural level.

The traditional Phillips curve was challenged in the 1970s when the economy experienced both low unemployment and inflation. It was then argued by monetarists that the Phillips curve's trade-off was a short-run phenomenon (Friedman 1968). In the short run, monetary policy can produce output as well as inflation changes, but in the long run, monetary policy simply influences prices. ${ }^{2}$ The natural rate of unemployment will emerge in the long run as expectations of inflation catch up to actual inflation. The only way to maintain unemployment below the natural rate, then, is to continually accelerate inflation.

In the longer run, a trade-off between output and inflation should not exist, as output is restored to its potential level. However, a trade-off between the volatility of output and inflation may indeed exist in 'New Consensus' models as argued by Taylor (1979). Although in levels the trade-off disappears, in terms of volatility, policymakers can choose the extent to which they respond to short-run deviations of output and inflation. Essentially, as short-run shocks cause deviations to the level of inflation or output, the monetary authority chooses the extent to which it wishes to push inflation and output back to their natural levels. If inflation is persistent, this may mean the authority will have to overreact (Chatterjee 2002). The monetary authority is thus not attempting to maintain permanently higher (lower) output or inflation, but instead to offset short-run shocks. The required overreaction, however, means that either output or unemployment will increase in variability. This generates a long-run Taylor curve in which the central bank can choose between decreased volatility in output or inflation. Taylor's (1993) famous 'rule' suggests that central banks respond to inflation and output gaps with equal weight.

The basic 'new consensus macroeconomics' (NCM) that emerged from the experience of the 1970 s includes a version of the basic monetary policy rule. ${ }^{3}$ The NCM model can be described in three basic equations (for instance, Arestis and Sawyer 2004; Carlin and Soskice 2005; Meyer 2001):

$$
y_{t}^{g}=\alpha_{0}+\alpha_{1} y_{t-1}^{g}+\alpha_{2} \xi\left(y_{t+1}^{g}\right)-\alpha_{3}\left[r_{t}-\xi\left(p_{t+1}\right)\right]+\varepsilon_{1}
$$

2. The short-run trade-off results from a host of imperfections - for instance, Lucas's (1972) signal extraction problem.

3. A description and critique of NCM can be found in Arestis and Sawyer (2004). 


$$
\begin{aligned}
& p_{t}=\beta_{1} y_{t}^{g}+\beta_{2} p_{t-1}+\beta_{3} \xi\left(p_{t+1}\right)+\varepsilon_{2} \\
& r_{t}-r^{*}=p_{t}+\gamma_{1}\left(p_{t-1}-p^{*}\right)+\gamma_{2} y_{t-1}^{g}
\end{aligned}
$$

In the above, $y^{g}$ reflects the output gap, $r$ is the nominal interest rate, and $p$ is the rate of inflation. Asterisks indicate the target or natural rates, $\xi$ indicates expectations of a particular variable, and $t$ the usual time subscript. Equation 1 suggests that output is a function of the past and expected future output gap, as well as the expected real rate of interest. Equation 2 is a standard expectations augmented Phillips curve. Finally, Equation 3 is a central-bank policy rule.

The obvious implication of the NCM model described above is to promote fiscally 'responsible' governments and independent central banks. A credible and independent central bank should thus be able to avoid the famous problem of time inconsistency. With the public no longer suspicious that central banks will renege on their policy announcements, the trade-off between output and inflation should be reduced. By simply committing to clear and consistent rules, central banks can make the pain of inflation stabilization substantially less.

In this framework however, a decline in inflation and output volatility simultaneously cannot be the result of a new mix of policy preferences. As Bernanke (2004) argues, the coincident decline in volatility could be because, prior to the Great Moderation, policy operated to the left of the Taylor curve. Thus, better policy would be able to move rightward onto the curve. Alternatively, the curve itself could shift to the right as a result of a structural change in the economy. A final cause of the decline in volatility could be the reduction in shocks that the central bank must respond to - a view that Bernanke believes cannot explain sustained declines in volatility. The literature on the causes of the Great Moderation can thus be conveniently separated into three basic causes: good policy, good luck, and structural change.

Explanations that rely on 'good policy,' then, suggest that the economy prior to the 1980s was operating outside of the Taylor curve. Clarida et al. (2000) is the classic paper on the good policy hypothesis. In that paper, the authors estimate monetary policy rules under pre- and post-Volcker Federal Reserve regimes, and find evidence of a shift in the policy rule as a source of macroeconomic stability. That is, the Federal Reserve is supposed to have more systematically responded to inflation and output deviations. In particular the Federal Reserve is supposed to have increased the interest rate by more than the deviation in inflation. Romer and Romer (2002) emphasize that large shifts in economic policy that occurred in the 1970s as a result of changes in the prevailing opinion of economists and policymakers. In their telling, prior to the Volker-Greenspan era, the Federal Reserve essentially believed that little could be done about inflation, which was primarily a cost issue. Additionally, the Federal Reserve was working under an assumed 'natural rate' of unemployment far below what Romer and Romer (2002) suggest could have been the case. They conclude that the Federal Reserve did not prioritize inflation in interest-rate decisions and thus let the real interest rate fall in times of inflation. What was lacking, according to Meltzer (2005) was a common theory of money and monetary policy among participants in the open-market committee. Taylor (1999) himself agrees and suggests that, without a clear policy rule, monetary policy was marked by 'policy mistakes' prior to the Great Moderation. ${ }^{4}$ Other authors that come to the good policy conclusion include Summers (2005), Bernanke (2004), and Benati and Surico (2008).

4. Taylor (2012) notably believes that the Federal Reserve abandoned sensible rules in favor of discretion by 2003. 
According to this view the central bank was not credibly committed to fighting inflation. In fact, several authors have argued that oil shocks could not be the primary cause of the inflationary period of the 1970s, as sustained inflation would not have been possible without accommodating monetary policy (see, for instance, DeLong 1997). Thus, while there may have been cost effects, the inflation, and its costly reduction, was ultimately due to the lack of credible policy rules by the Federal Reserve. Stable inflation, in turn, should lead to stable output.

Explanations that focus on 'luck' typically emphasize the decline in shocks (as opposed to propagation mechanisms). Stock and Watson (2003) use a structural vector autoregression (SVAR) to investigate the role of output shocks internationally. Though they are unsure what shocks matter, they emphasize that changes in propagation cannot explain the full decline in volatility. Ahmed et al. (2004) find similar declines in shocks, with a similar lack of identification of particular shocks. Justiniano and Primiceri (2008, p. 610) are more explicit and suggest a reduction in 'investment specific technology shocks.' In their view, these are the result of a decline in financial friction (and thus better capital allocation). Proponents of the 'good luck' hypothesis thus tend to focus on unforecastable disturbances in VAR models, but in general are not specific about what shocks are declining. While some popular varieties of the good luck hypothesis focus on oil-price shocks (Hamilton and Herrera 2004), we will suggest in the following section that these shocks may actually be endogenous to monetary policy.

A final category of explanation is the structural change hypothesis. Most often, the structural change hypothesis has focused on inventory management. McConnell and Perez-Quiros (2000) suggest that a decline in GDP volatility can be traced to a decline in the share of inventories in durable goods production. This explains the observed decline in the volatility of durable goods production, while the volatility of durable goods sales has remained stable. Kahn et al. (2002) have argued that greater information has made predicting demand patterns easier, and thus inventory-to-sales ratios have declined. In general, then, one could argue that the structural change may have affected the slope of Phillips and Taylor curves.

\section{POST-KEYNESIAN INFLATION}

The improved policy hypothesis has perhaps garnered the most attention, particularly among central bankers. The difficulty with this story is that while the Federal Reserve may have prioritized inflation with the arrival of Volker, it isn't clear that independent, rule-bound central banks actually do result in better inflationary experiences. Inflation targeting and independent central banks may actually have come on the 'heels of a decade of low inflation,' as Dueker and Fischer (2006, p. 448) put it. That is, in the context of already-declining inflation, it is hard to isolate a major influence of inflation-targeting rules. This is in line with broader evidence that interest rates have little influence on the rate of inflation, as argued by Arestis and Sawyer (2004), and that an output-inflation-volatility trade-off has questionable empirical support (Arestis et al. 2002).

The post-Keynesian models of inflation do not rely on natural rates as in the NCM model. Indeed, as Galbraith (1997) argues, the notion that there is a rate of unemployment (or output) beyond which inflation is accelerating suffers from both theoretical and empirical problems. In addition, following Keynes (1936), the post-Keynesian macroeconomic vision rejects the concept of a Wicksellian natural rate of interest. 
Instead, cost-push inflation is emphasized, which in turn is often related to distributional conflict. At the microeconomic level, post-Keynesian pricing models all rely in some form or another on cost-plus pricing. In addition, in these models money is typically endogenous (Smithin 2003). The rate of unemployment or activity may thus influence wage demands or commodity prices, but in general post-Keynesians reject any unambiguous relation between these variables and the rate of inflation.

Inflation, then, is often the result of inconsistent claims on output, as wages exert the main pressure on costs. Though some heterodox models endogenize wage demands, wages are often considered to have a strongly exogenous element that is historical and dependent on bargaining conditions. ${ }^{5}$ To the extent that these wage demands grow faster than labor productivity, firms have the choice to either reduce costing margins, or attempt to pass on these costs into prices. ${ }^{6}$ In addition, as structuralist authors emphasize, cost pressures can come from commodity-price shocks and exchange-rate depreciation, the effects of which are then resisted by labor. ${ }^{7}$

Thus, rather than poor monetary policy, post-Keynesians focus on cost factors to explain the rising inflation of the 1970s. Supply-side shocks, when passed on in prices, resulted in wage pressures as workers' bargaining power was comparatively strong in the Golden Age policy regime. For instance, Kaldor (1976) emphasizes changes in commodity buffer-stock policy and oil shocks, which were then amplified by wage resistance. The inflation subsided, not as a result of 'good policy' but of a decline in the labor movement.

The general view of post-Keynesian cost, pricing, and inflation theory finds some degree of confirmation in the empirical literature. Coutts et al. (1978) conducted a large-scale study of industrial pricing in the UK and found evidence for what they call the 'normal price hypothesis' which suggests that firms mark up costs at 'normal' output (a view earlier espoused by Kalecki 1938 and Means 1935). More recent contributions include Atesoglu (1980), who compares the wage cost mark-up model to monetary models and finds the wage cost version to be superior. Atesoglu (1997) then endogenizes the growth of wages (to the level of unemployment) in a similar mark-up model and finds a good fit using US data. Additionally, Bloch, Dockery and Sapsford (2004), who estimate a mark-up model for US inflation, find that commodity prices and wages are largely passed through to inflation. In this paper, we build on the empirical post-Keynesian tradition by developing a VAR model that is designed to test the post-Keynesian mark-up model as compared to the good policy hypothesis during the 'Great Moderation.'

\section{THE DATA}

The data are in quarterly format and stretch from Q1 of 1982 to Q4 of 2006. The empirical section will use several variables to test the determinants of inflation, including a Taylor rule differential, oil prices, import prices, wages, and the exchange rate. Data sources are listed in Appendix A1.

5. See Taylor (2004) for models that relate the wage to capacity utilization.

6. Thus, wages are considered to be determined by the political economy of wage bargaining, not by marginal productivities.

7. See, for instance, the description of inflation in Sunkel (1976). 


\subsection{The Taylor rule differential}

The Taylor rule, derived from Equation 3 above, is calculated as follows:

$$
r_{t}=p_{t}+r^{*}+\gamma_{1}\left(p_{t-1}-p^{*}\right)+\gamma_{2} y_{t-1}^{g} .
$$

Following Taylor (1993), the coefficients on inflation and the output gap are assumed to be weighted each at 0.5 , illustrating a dual mandate between inflation and unemployment. The equilibrium federal funds rate is assumed to be 2 percent and the inflation target 2 percent, while the inflationary expectations is calculated as the average of the previous four quarters of inflation. ${ }^{8}$ The deviation from the Taylor rule is then calculated as the difference between the predicted Taylor rule and the actual Federal Funds rate. This variable will be a test of whether 'good policy' has had a legitimate effect on curbing inflation and its volatility. In using the differential between a 'benchmark' Taylor rule and actual Fed policy, we are following Taylor (1999) himself, who uses these deviations to explain historical macroeconomic outcomes. If good policy is the reason for lower inflation and lower inflation volatility, then as the Taylor rule deviation gets higher, inflation will increase. If good policy is important, then the impulse response functions will show that a positive shock to the Taylor rule will cause inflation to rise. The Taylor rule differential was devised for this test because the Taylor rule is the best representation of 'good policy' that can be quantified. The Taylor rule also represents the majority view of economists as to how to conduct monetary policy. The authors have not found another paper that uses a Taylor rule differential to test the good policy hypothesis, so we consider it unique to the literature.

Figure 2 shows the relationship between the Taylor rule and the Federal Funds rate, with the Taylor rule generally higher than the Federal Funds rate for the 30 years of data. Figure 3 shows the relationship between the Taylor rule differential and the inflation rate. Visually, there is a strong relationship in the 1980s between the Taylor rule differential and the inflation rate. As the differential gets high, inflation gets higher. The strong relationship in Figure 3 does not necessarily imply causality. They may each be following a trend caused by a third variable or other economic factors.

\subsection{Wages}

The Employment Cost Index from the Bureau of Labor Statistics is used as the primary measure of wages. ${ }^{9}$ This accurately reflects the costs to business that would affect prices in a mark-up model. Figure 4 shows a distinct drop in wages that begins in 1980 and maintains itself until wage volatility increases near 2006. The drop in wages coincides almost perfectly with the decline in the inflation rate and inflation volatility. There are several explanations for the fall in wages during this time period. The first is the loss of collective bargaining and declining union membership as shown in Figure 5. There is a distinct drop in union membership at the same time (19801982) as the fall in inflation and wages. This occurs at the same time as productivity

8. The GDP deflator was used for the measure of inflation in the inflation gap, while CPI was used to measure inflation expectations since consumers react to announcements in CPI rather than the GDP deflator.

9. Other measures of wages were used, including manufacturing wages (IMF, International Financial Statistics (IFS)) and unit labor costs, which each showed similar results in the model. 


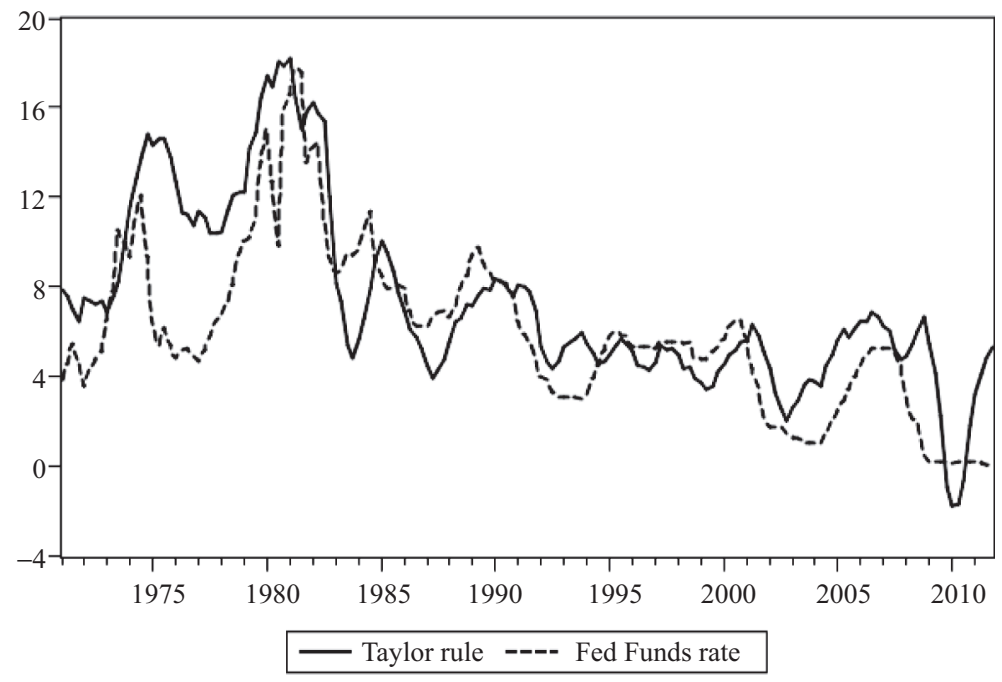

Figure 2 Taylor rule differential and Fed Funds rate

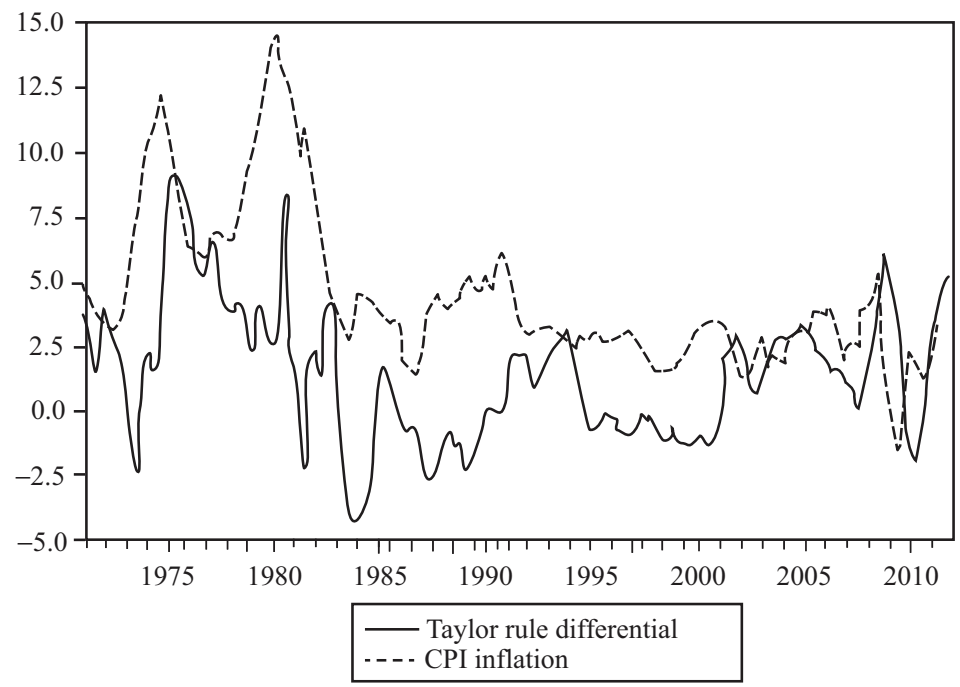

Figure 3 Taylor rule differential and inflation

breaks away from compensation (Figure 6) and workers stop receiving pay increases to keep up with productivity.

A second factor in the decline of US wages may be increased international competition. Businesses relocate to areas with cheaper manufacturing costs and US workers are forced to take lower wages to compete for manufacturing. There is an exchangerate aspect to this story, although the impact should be smaller than other factors discussed. Because the US holds the hegemonic currency, demand for dollars and 
484 Review of Keynesian Economics, Vol. 4 No. 4

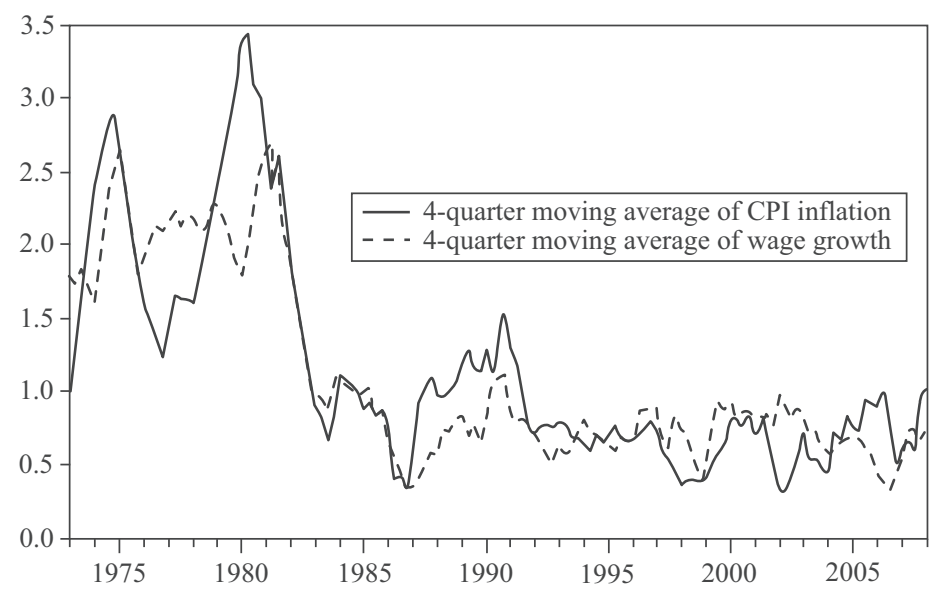

Figure 4 Inflation and nominal wage changes

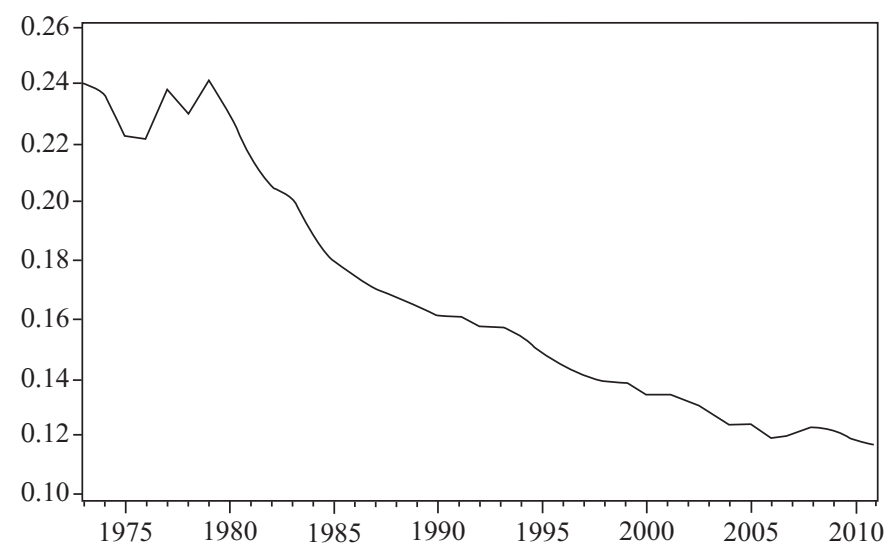

Figure 5 Union membership as a percentage of labor force

treasury bonds is always very high. This increases the value of the dollar beyond what it would be if the US were not the global hegemon. High interest rates in the 1980s and high growth in the 1990s, and a booming stock-market relative to world growth and world stock markets kept demand for dollars high, which appreciated the US dollar. This appreciated dollar made it difficult for exporting businesses to compete. Not only were costs cheaper in other countries in the global economy, but exchange-rate effects accelerated the losses to US manufacturing, eventually leading to lower wages.

In terms of productivity, neoclassical theory argues that the difference between productivity and wages is the marginal productivity of capital, or technology. Wages are paid according to their marginal productivity of labor, so if wages fall and productivity rises, it must be that capital is driving productivity. This same explanation can be given to justify the large disparity in income distribution during the same time period. This paper takes the point of view that wages are not automatically paid the marginal 


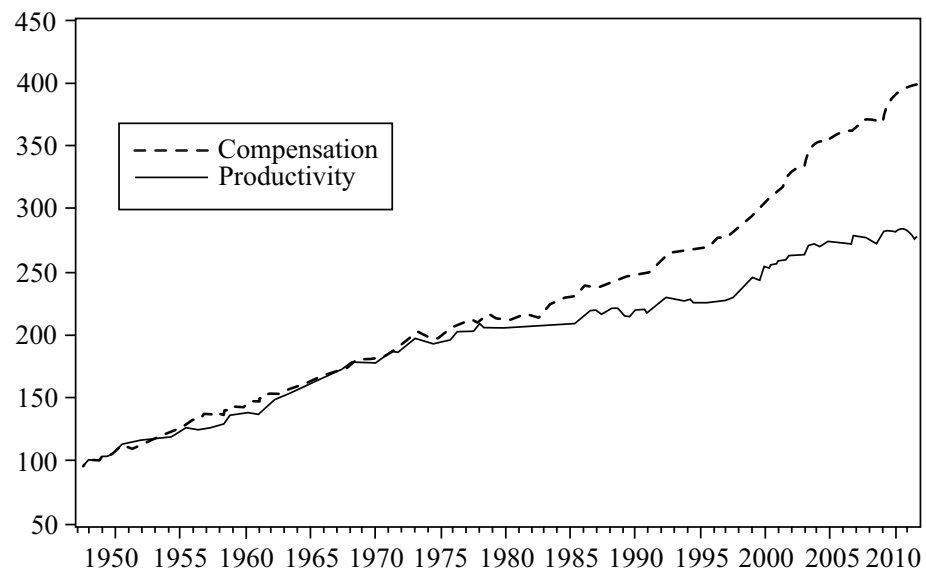

Figure 6 Productivity and real hourly compensation

productivity of labor, but are paid in accordance with their bargaining or political power. Workers are no longer being compensated for their productivity at the same level they were during the previous 30 years, which has reduced wage costs and therefore inflation. Aside from Reagan-era anti-union policies, high interest rates and an overvalued exchange rate helped reduce exports and increase the volume of evercheaper imports, reducing wages especially in the manufacturing sector, which had a high unionization rate and high wages. The empirical model will attempt to shed light on this as well as disseminate the effects in this highly endogenous system.

\subsection{Exchange rates and import prices}

Import prices noticeably declined in the early 1980s due to international competition, cheap world labor costs, and increasing trade (Figure 7). As with wages, the US dollar exchange-rate appreciation also played a role in reducing import prices. Neoclassical theory focuses on exchange-rate determination as derived from purchasing power parity. In the long run, exchange rates are merely a function of two countries' inflation rates, and the exchange rate adjusts for the two countries' inflation rates. Post-Keynesians emphasize the role of exchange rates on inflation by means of pass-through effects and cheaper import prices. The chain of causality is as follows. The Federal Reserve increases interest rates, and exchange rates climb because of the increase in demand for treasury bonds. As exchange rates increase, the price of imports falls. American consumers purchase more foreign goods, which eliminates American companies' profits in manufacturing. As prices fall in the manufacturing sector, wages are cut. Inflation then falls in response to this chain of events. The exchange rate is not a passive adjustment mechanism between two countries; it can be a means of inflation transmission due to domestic and international policy. The nominal trade-weighted exchange rate for the US dollar against its primary trading partners was used. ${ }^{10}$ The nominal exchange rate is used to capture

10. Data is from the IMF International Financial Statistics (IFS), and is an index based on prices in US dollars. 


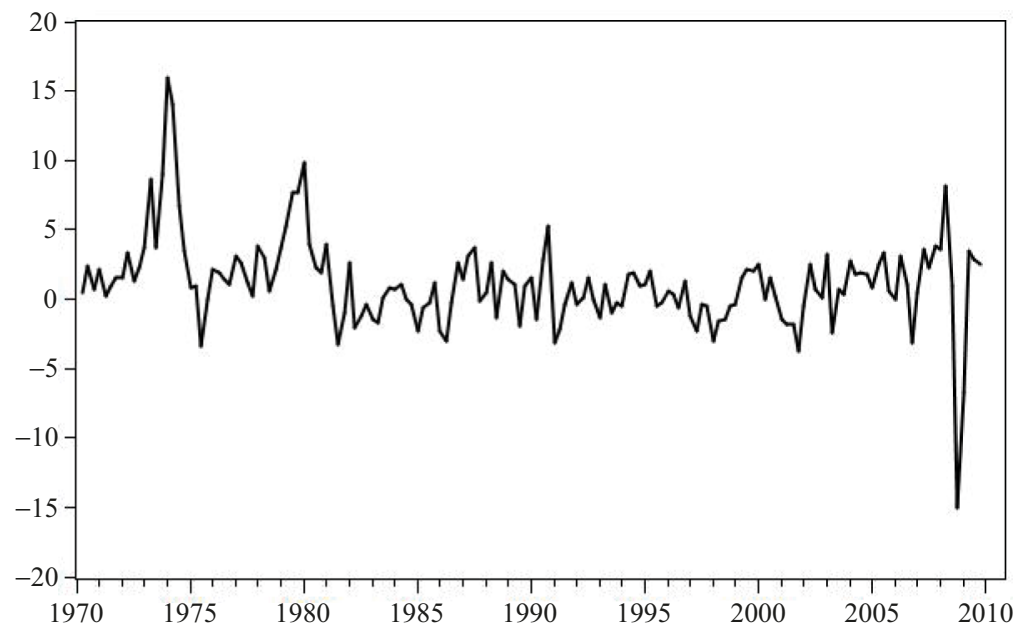

Figure 7 Import price percentage change

the pass-through effects of exchange rates to import prices, commodities, and then to inflation. It is important to note that it was not just the United States that experienced a great inflation moderation; several countries did. This leads many authors to look for the common world factor that reduced inflation. While the driving factor of the inflation moderation is likely to be factors that are similar in other countries with the same experience, this does not mean that there are not country-specific factors that can have an important impact (see Summers 2005). The US hegemonic currency, its appreciation in the 1980s and the domestic effect on wages and import prices are an important aspect of the story for the US.

\section{THE EMPIRICAL MODEL}

The empirical model is set up to test the causal factors and their contributions to the changes in inflation. The empirical model uses a recursive VAR which follows postKeynesian principles in the ordering of the variables. ${ }^{11}$ The impulse response functions and the variance decomposition are obtained by applying the Choleski decomposition which produces orthogonal innovations. The ordering is important because the contemporaneous innovations for all of the variables on the left-hand side will impact all the other variables on the right-hand side, whereas the variables ordered last will not have a contemporaneous effect on the left-hand side variables.

The Taylor rule differential will tell us whether inflation or disinflation is the consequence of deviating too far from the Taylor rule. Import prices are used to show the effect of low import costs on falling inflation. The primary method by which import prices fall is through a rise in the exchange rate. Oil is included to test the hypothesis

11. The VAR follows a Choleski decomposition identification strategy. This avoids the problem of correlated errors and allows for interpretable impulse response functions and variance decompositions. 
that many Great Moderation papers have included, that 'exogenous' oil shocks are responsible for lower inflation in the Great Moderation. The order of the variables starts with the Taylor rule differential, since the Federal Reserve controls the shortterm interest rate and can choose whether to deviate from the 'rule.' Next is the exchange rate, since exchange-rate fluctuations are primarily determined by changes in interest rates (Harvey 2006). This is followed by import prices and then oil prices, since both import prices and oil prices are assumed to be affected to some degree by changes in the exchange rate. Wages in part respond to exchange-rate changes and the falling import prices that put pressure on domestic workers and labor bargaining. And, finally, inflation responds to all of these variables contemporaneously. ${ }^{12}$ This ordering is in the post-Keynesian tradition for three primary reasons:

1. It is assumed that exchange rates are not driven by purchasing power parity, or that inflation is not the only or primary causal factor in exchange-rate fluctuations (Harvey 1991). In this model, exchange-rate effects can affect inflation first (pass-through effects) before inflation can affect the exchange rate.

2. The role of wages in reducing inflation draws upon two points. The first is that workers are not paid according to their marginal productivity of labor, and are in fact subject to collective bargaining and class conflict. The second is that unionization has declined and wages have been pushed down.

3. The model assumes that money is endogenous. If money supply changes caused inflation to change, money supply would need to be included in this model. Because money is considered endogenous, and it is assumed that the central bank only has control over short-term interest rates and not the money supply, the money supply variable is omitted from the model.

Two important points need to be made about the ordering of oil and the exchange rate. The first is the relationship between oil and exchange rates. Oil is generally assumed to be exogenous because supply decisions are made by the Organization of the Petroleum Exporting Countries (OPEC) or other oil-exporting countries. Or, in more severe cases where war decisions threaten global supply, the price shock may be exogenous. However, oil prices can be argued to be endogenous in this system in two ways. The first is that oil output decisions are made with world demand in mind. In other words, oil production decisions take into account the demand of the customers (growth), which makes oil endogenous to the system above. The second way in which oil is endogenous is that exchange-rate fluctuations can affect the oil-production decisions of OPEC. Because the dollar is the international reserve currency, oil and other commodities are sold in dollars which creates a special relationship between commodities and oil. Suppose OPEC has a profit goal of a set mark-up on oil prices, which are highly inelastic. When OPEC countries sell oil they receive dollars, which means in order to spend these dollars they have to be recycled or converted into the domestic currency. When the US dollar is high in value, the price does not have to be as high to adjust for exchange-rate effects. When the US dollar is low in value, oil must be priced higher in order to meet the same profit targets. As the financial system has increased in sophistication, hedging and speculating have become an integral part of the oil-dollar relationship. Now when international investors believe the US dollar is going to fall, instead of

12. Other orderings were tried, including import prices, ER, oil, wages, CPI, and Taylor rule. This accounts for the potential that Federal Reserve policy, although exogenous, reacts after these other variables have moved. The results of this ordering are in Appendix A2. 


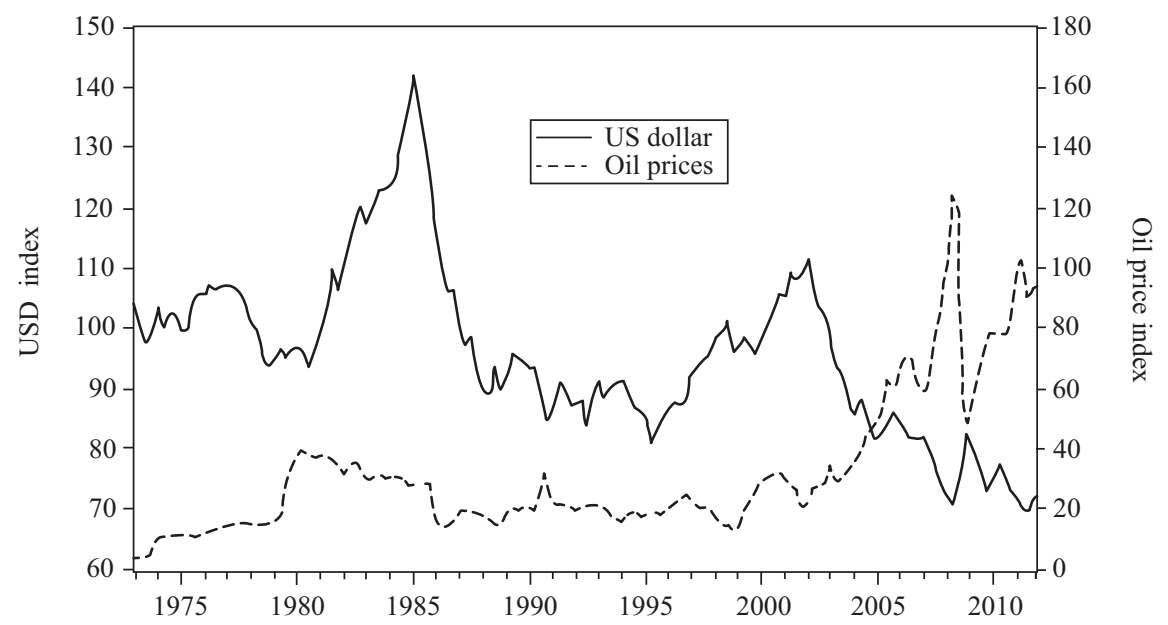

Figure 8 US dollar index and oil price index

selling out of their positions to avoid the exchange-rate loss, they will buy assets that they believe will go up in value as the dollar falls. A favorite US dollar-hedging device on Wall Street is oil, which makes oil highly endogenous in this system. This is apparent in Figure 8.

Because of this, oil is listed after the exchange rate. This implies that the innovations of the exchange rate can affect oil contemporaneously, but that oil prices cannot affect the exchange rate contemporaneously.

In contrast, a standard neoclassical model addressing the ordering of the variables to determine the causes of the Great Moderation may look like the following. Money supply would be listed first because the Fed is assumed to control the money supply. Interest rates are determined by the manipulation of the money supply and listed second. Inflation would be third, because inflation is a direct result of changes in the money supply. Since the labor market and the trade-off between labor and leisure combined with the production function ultimately determines the level of output, wages would be listed fourth. And finally, exchange rates would be listed after inflation, since purchasing power parity is the ultimate determinant of exchange rates. Many VARs are sensitive to the ordering of the variables, and the assumptions of the model can shape the empirical results. As evidence of robustness of this empirical model, the ordering of the variables does not change the basic results. In several different orderings, the basic premise that inflation is cost-push through wage and exchange rate effects holds.

DF-GLS tests were performed on the variables and the test indicated that to create stationarity the variables should be differenced (Table 2). ${ }^{13}$ All variables are first differenced to account for the non-stationarity of the variables in their level form, and the log of each variable is taken and used in a vector autoregression. For this model a standard VAR is better than a structural VAR for several reasons. The first is that a

13. In the DF-GLS test performed, the Augmented Dickey-Fuller test is augmented by transforming the time series via generalized least squares (GLS) regression before performing the test. 
Table 2 ADF-GLS tests ${ }^{\mathrm{a}}$

\begin{tabular}{lcc}
\hline Variable & In levels & In first differences \\
\hline lnCPI (lags 11, 1) & -0.526 & $-5.131^{*} * *$ \\
lnER (lags 3, 2) & -1.728 & $-3.347^{* *}$ \\
lnEmploymentCostIndex (lags 11, 10) & -0.691 & $-2.845^{* *}$ \\
lnImportprices (lags 11, 4) & -2.307 & $-3.459^{* * *}$ \\
lnOil (lags 3,5) & -1.562 & $-3.146^{* * *}$ \\
lnTaylorruleDifferential (lags 11, 10) & -1.345 & $-6.698^{* * *}$ \\
\hline
\end{tabular}

Notes:

a. The data is defined as follows: $\operatorname{lnCPI}$ is the non-seasonally adjusted natural log of the CPI; $\operatorname{lnER}$ is the natural $\log$ of the nominal US dollar exchange rate (weighted for major trading partners); lnEmploymentCostIndex is the natural log of the non-seasonally adjusted Employment Cost Index for all civilians; lnImportprices is the natural log of the IMF's import price index (non-seasonally adjusted); lnOil is the natural log of the the nominal West Texas Intermediate spot price; InTaylorRuleDifferential is the difference between the predicted Taylor rule and the actual Federal Funds rate (explained in the data section). For more information, see Appendix A1.

b. Ng-Perron (1995) sequential $t$-test criterion is used to select optimal lag length.

$* * *$ Indicates significance at the $99 \%$ level; ${ }^{* *}$ indicates significance at the $95 \%$ level; ${ }^{*}$ indicates significance at the $90 \%$ level.

structural VAR is only as good as the strict identifying assumptions imposed on the matrix. To have a perfectly identified SVAR with six variables would require imposing up to fifteen restrictions. ${ }^{14}$ Practitioners of SVARs can impose strict assumptions of causality on the variables, and oftentimes impose these restrictions for mathematical ease or for the sake of the identifying restrictions being triangular, which is a popular strategy. In other words, SVARs are only as good as the strict restrictions imposed on the variables, and these restrictions are prone to bias and the necessity for mathematical ease, which can produce preconceived results (Sims 1986). The authors of this paper see this as a weakness and use a standard VAR technique that allows all variables to be, in a sense, causal, to effectively capture the interaction between a complex set of macroeconomic variables. Virtually every combination of variables listed above can be argued from one perspective or another to be causal or connected with another variable in some way. A standard VAR is the most useful macroeconometric tool because of this issue. ${ }^{15}$ The VAR uses four lags as selected using the Akaike information criterion (AIC). Data for the employment cost index, import prices, and the CPI were not seasonally adjusted for this model. Instead, seasonal dummy variables were used to control for seasonality. ${ }^{16}$

14. To identify the structural model from an estimated VAR, it is necessary to impose $\left(n^{2}-n\right) / 2$ restrictions on the structural model (Enders 2004).

15. A Vector Error Correction Model (VECM) was considered but the authors decided against addressing the cointegration issue because cointegration assumes long-run equilibrium between some of the variables. The idea that there is a long-run equilibrium that can be empirically measured contradicts the belief of many post-Keynesians that markets may not always return to equilibrium, or that equilibrium outside of an abstract concept even exists. Ultimately the paper is about the causality of variables to inflation and not about short- and long-run deviations from equilibrium between cointegrated variables.

16. The use of seasonal dummy variables is discussed in Patterson (2000, pp. 272-273). 


\section{RESULTS}

The impulse response functions (IRF) for the model are shown in Figure 9, and variance decompositions (VD) for the CPI are listed in Table 3. IRFs and VDs show that the Taylor rule is not sufficient to explain inflation during the Great Moderation period. The IRF shows that a positive shock to the Taylor rule differential has an ambiguous if not slightly negative effect on inflation. The IRF is negative for seven out of the first nine periods, which is the opposite of the expected result, and then goes positive after nine periods. The VDs show that the amount of variation of inflation that the Taylor rule can explain is approximately 3.6 percent and this is after almost six quarters of data. We can also say that the Taylor rule effect is significantly smaller compared to the other factors in the model. This is important because the NCM relies on the Taylor rule to control inflation. The Taylor Rule Differential measures the difference between the predicted Taylor rule and the actual Federal Funds Rate. If the actual rate is lower the natural rate, we should see a positive impact on inflation. The IRF illustrates a slightly negative if not ambiguous impact, and the VD is very low. This implies deviations of the actual rate of interest from the natural rate of interest are not as important in the determination of inflation as other factors. ${ }^{17}$

The exchange-rate IRF shows that as the exchange rate increases, inflation increases for the first four quarters. After this initial effect, the increased exchange rate begins to reduce inflation. The aggregate effect over twenty quarters shows that an increase in the exchange rate reduces inflation. The reason for the initial increase in inflation due to a positive exchange-rate shock is not entirely clear. It can be partially explained by $J$-curve effects, or the expected delay in exchangerate pass-through effects due to previous trade contracts. The VD shows that the exchange rate explains approximately 3.6 percent of the percentage contribution of innovations from the exchange rate to inflation over 6 periods. This does not mean the exchange rate is not important; it merely means that the chain of effects must be explained. Because this model also includes oil prices and import prices, the direct effect of the exchange rate is, in a sense, controlled for. The more important finding is that both oil prices and import prices respond directly to changes in the exchange rate. As the exchange rate appreciates, import prices fall and so do oil prices, although oil prices follow more precisely the pattern of the exchange rate over the first two quarters. The VDs support the causality of the transmission of import prices and oil prices through the exchange rate.

The results for import prices show that they are vital to explaining falling inflation in the Great Moderation period. The IRF shows that a positive shock to import prices causes an increase in inflation. As discussed above, the fall in import prices is due to globalization, lower overseas wages, and to a lesser extent exchange-rate effects. The impact of exchange rates on import prices is also clear in the results. VDs for import prices show that import prices can explain almost 50 percent of the variation in inflation.

17. Note that in Appendix A3 a modified Taylor rule is used which moves away from the specific Taylor rule calculation (Taylor 1993) to a more realistic model of how the Federal Reserve actually tracks inflation (that is, use of personal consumption expenditures, and a forward-looking inflation expectations measure). The IRF for the Taylor Rule Differential in the modified Taylor rule is positive (which is the expected sign) and more significant, but still relatively weak. See Appendix A3 for details. 

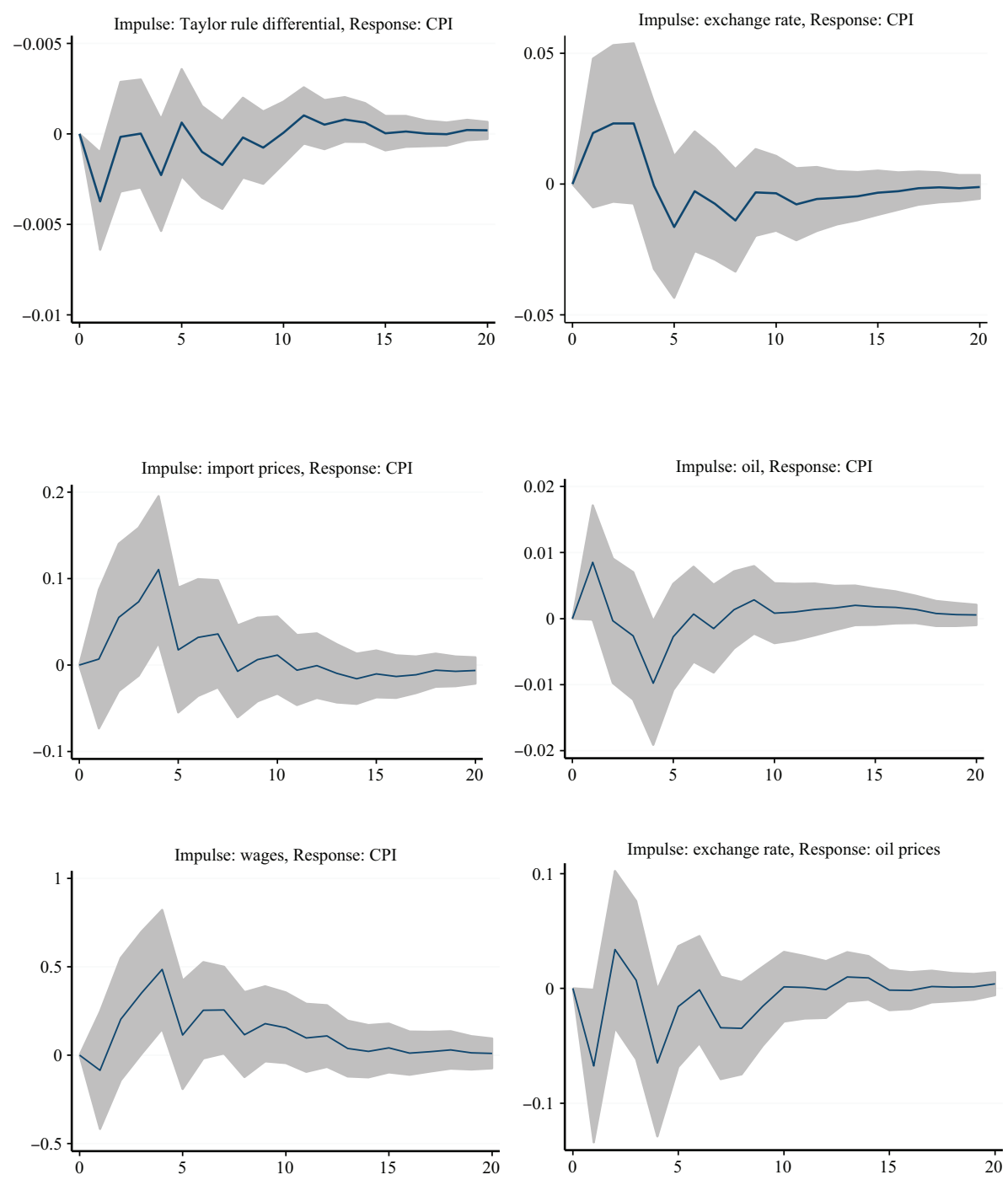

Note: All variables are in $\operatorname{logs}$ and the first difference of the variables are taken, as stated in the text. Confidence intervals represent $95 \%$ confidence.

\section{Figure 9 Impulse response functions}


492 Review of Keynesian Economics, Vol. 4 No. 4
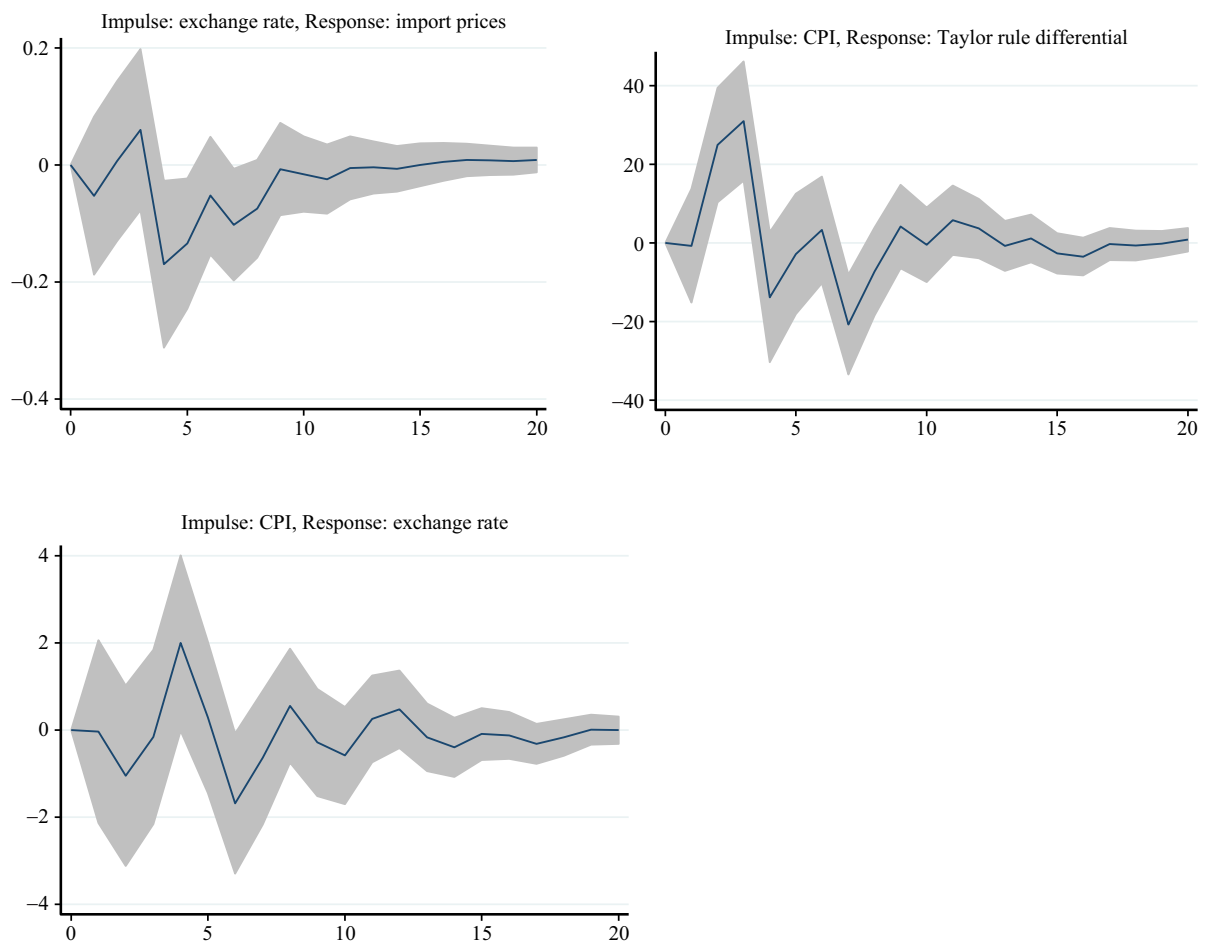

Figure 9 (continued)

Table 3 Variance decomposition CPI

\begin{tabular}{lcccccc}
\hline $\begin{array}{c}\text { Variance decomposition } \\
\text { of the CPI (response) }\end{array}$ & \multicolumn{3}{c}{$\begin{array}{c}\text { Impulse } \\
\text { variable }\end{array}$} & & & \\
\hline Horizon & CPI & Taylor rule & $\begin{array}{c}\text { Exchange } \\
\text { rate }\end{array}$ & $\begin{array}{c}\text { Import } \\
\text { prices }\end{array}$ & Oil prices & Wages \\
\hline 1 & 0.4030 & 0.0067 & 0.0021 & 0.5737 & 0.0001 & 0.0143 \\
2 & 0.3290 & 0.0168 & 0.0064 & 0.5816 & 0.0290 & 0.0121 \\
3 & 0.3555 & 0.0281 & 0.0201 & 0.5435 & 0.0270 & 0.0144 \\
4 & 0.3262 & 0.0359 & 0.0284 & 0.5427 & 0.0270 & 0.0386 \\
6 & 0.2848 & 0.0363 & 0.0361 & 0.5105 & 0.0528 & 0.0793 \\
10 & 0.2772 & 0.0367 & 0.0428 & 0.4890 & 0.0542 & 0.0998 \\
20 & 0.2742 & 0.0395 & 0.0449 & 0.4783 & 0.0583 & 0.1042 \\
\hline
\end{tabular}

A positive shock to oil prices increases inflation for the first three periods, but falls for periods 4 and 5, and then returns positive after that. The VD shows that oil can explain approximately 5.2 percent of the variation in inflation after 6 periods. In this model, oil is assumed to be endogenous in the sense that not only can supply 
and demand for oil affect oil prices, but to a lesser extent the demand and supply decisions for oil are based on exchange-rate effects. Adjusting for this shows that oil can have an impact on inflation, but it is not significant enough to explain the Great Moderation, as some authors have claimed. And more specifically, when controlled for the endogenous nature of oil prices, the effect is smaller than the 'good luck' literature suggests.

The IRF for employment cost index shows that a positive increase in wages causes a clear positive increase in inflation. Wages have the second-highest magnitude of impact after import prices. Earlier it was illustrated that wages have fallen during the Great Moderation period, which implies that, as wages have fallen, inflation has fallen. The VD shows that wages explain up to 10 percent of the variation in inflation after the full twenty quarters. It is not surprising that wages take time to have their full effect on inflation due to the rigid nature of wages. This result can be interpreted as evidence for both a domestic attack on wages through the reduction in labor union membership and increased international competition that has put competitive pressure on US wages. This was facilitated further by the exchange-rate effects and international competition effects on the US manufacturing base, which was highly unionized and kept wages high.

The following can be summarized from the results:

1. Oil prices are not strong enough to explain the Great Moderation, contrary to the 'good luck' or oil hypothesis.

2. Monetary policy as measured by a Taylor rule differential is not strong enough to explain the Great Moderation, contrary to the 'good policy' literature.

3. Falling wages and falling import prices are the primary determinants of the low inflation rate during the great moderation. The US has benefited from reduced wages due to international competition, decreased labor bargaining, and a fall in exporting due to a combination of external competition (relatively cheap foreign labor) and exchange-rate effects. Import prices have fallen for many of the same reasons.

\section{CONCLUSION}

Traditional explanations of the Great Moderation fall into three categories: good luck, good policy, and structural changes. This paper has tested both the good luck and good policy hypotheses in a post-Keynesian mark-up model and determined that it is neither good policy nor good luck that caused the great inflation moderation. The Great Moderation was, in fact, a great wage and import price moderation that stabilized and pushed prices down. The implications of this study are important. First of all, monetary policy assuming a Wicksellian natural rate of interest, or what is referred to as the Taylor rule, may not be the important policy tool that theorists have imagined it to be. Another implication is the role of good luck. Oil prices are important to the great inflation moderation, however the good luck literature does not understand the endogenous nature of oil prices and how they are related to the exchange rate. To lower oil prices and their role in inflation, one would need only to increase the value of the US dollar to push oil prices lower. This, of course, has other implications on different sectors of the economy which are beyond the scope of this paper. Another implication is that inflation has fallen at the cost of wages to workers. Inflation has in large part fallen because workers have taken 
consistent wage cuts, lowering the cost of business and reducing prices. And lastly, the great inflation moderation was mostly due to increased international competition and exchange-rate effects lowering import prices.

\section{REFERENCES}

Ahmed, S., A. Levin, and B.A. Wilson (2004), 'Recent US macroeconomic stability: good policies, good practices, or good luck?' The Review of Economics and Statistics, 86(3), 824-832.

Arestis, P. and M. Sawyer (2004), Re-examining Monetary and Fiscal Policy for the 21st Century, Cheltenham, UK and Northampton, MA: Edward Elgar.

Arestis, P. and M. Sawyer (2008), 'New consensus macroeconomics and inflation targeting: Keynesian critique,' Economia e Sociedade, 17, 629-654.

Arestis, P., G. Caporale, and A. Cipollini (2002), 'Does inflation targeting affect the trade-off between output gap and inflation variability?' The Manchester School, 70(4), 528-545.

Atesoglu, H.S. (1997), 'A post Keynesian explanation of US inflation,' Journal of Post Keynesian Economics, 19(4), 639-649.

Atesoglu, H.S. (1980), 'Inflation and its acceleration: evidence from the postwar United States,' Journal of Post Keynesian Economics, 3(1), 105-115.

Benati, L. and P. Surico (2008), 'Evolving US monetary policy and the decline of inflation predictability,' Journal of the European Economic Association, 6(2-3), 634-646.

Bernanke, B.S. (2004), 'The Great Moderation,' Remarks at the meetings of the Eastern Economic Association, Washington, DC, 20 February.

Bezemer, D.J. (2009), “No one saw this coming”: understanding financial crisis through accounting models,' unpublished.

Blanchard, O. and J. Simon (2001), 'The long and large decline in U.S. output volatility,' Brookings Papers on Economic Activity, 2001(1), 135-164.

Bloch, H., A.M. Dockery, and D. Sapsford (2004), 'Commodity prices, wages, and US inflation in the twentieth century,' Journal of Post Keynesian Economics, 26(3), 523-545.

Carlin, W. and D. Soskice (2005), 'The 3-equation New Keynesian model: a graphical exposition,' The B.E. Journal of Macroeconomics, 5(1), 1-38.

Chatterjee, S. (2002), 'The Taylor curve and the unemployment-inflation tradeoff,' Business Review, Federal Reserve Bank of Philadelphia, Q3, 26-33.

Clarida, R., J. Gali, and M. Gertler (2000), 'Monetary policy rules and macroeconomic stability: evidence and some theory,' The Quarterly Journal of Economics, 115(1), 147-180.

Coutts, K., W. Godley, and W. Nordhaus (1978), Industrial Pricing in the United Kingdom, Cambridge, UK: Cambridge University Press.

DeLong, J.B (1997), 'America's peacetime inflation: the 1970s,' in C. Romer and D.H. Romer (eds), Reducing Inflation: Motivation and Strategy, Chicago: University of Chicago Press for NBER, pp. 247-280.

Dueker, M.J. and A.M. Fischer (2006), 'Do inflation targeters outperform non-targeters?' Review, Saint Louis Federal Reserve, 88(5), 431-450.

Enders, W. (2004), Applied Econometric Time Series, Hoboken, NJ: Wiley.

Friedman, M. (1968), 'The role of monetary policy,' The American Economic Review, 58(1), $1-17$.

Galbraith, J.K (1997), 'Time to ditch the NAIRU,' The Journal of Economic Perspectives, 11(1), 93-108.

Godley, W. (1999), Seven Unsustainable Processes: Medium-Term Prospects and Policies for the United States and the World, Strategic Analysis, Annandale-on-Hudson, NY: Levy Economics Institute of Bard College, January.

Grabel, I. (2003), 'Ideology, power and the rise of independent monetary institutions in emerging economies,' in J. Kirshner (ed.), Monetary Orders: Ambiguous Economics, Ubiquitous Politics, Ithaca, NY: Cornell University Press, pp. 25-53. 
Hamilton, J.D. and A.M. Herrera (2004), 'Comment: oil shocks and aggregate macroeconomic behavior - the role of monetary policy,' Journal of Money, Credit and Banking, 36(2), 265-286.

Harvey, J. (1991), 'A Post Keynesian view of exchange rate determination,' Journal of Post Keynesian Economics, 14(1), 61-71.

Harvey, J. (2006), 'Post Keynesian versus neoclassical explanations of exchange rate movements: a short look at the long run,' Journal of Post Keynesian Economics, 28(2), 161-179.

Justiniano, A. and G.E. Primiceri (2008), 'The time-varying volatility of macroeconomic fluctuations,' The American Economic Review, 98(3), 604-641.

Kahn, J.A., M.M. McConnell, and G. Perez-Quiros (2002), 'On the causes of the increased stability of the US economy,' Federal Reserve Bank of New York Economic Policy Review, May, 183-202.

Kaldor, N. (1976), 'Inflation and recession in the world economy,' The Economic Journal, December, 703-714.

Kalecki, M. (1938), 'The determinants of distribution of the national income,' Econometrica, 6(2), 97-112.

Keen, S. (2006), 'The recession we can't avoid?' Steve Keen's Monthly Debt Report, November, Steve Keen's Debtwatch, Sydney, 1, 21.

Keen, S. (2013), 'A monetary Minsky model of the Great Moderation and the Great Recession,' Journal of Economic Behavior \& Organization, 86, 221-235.

Keynes, J.M (1936), The General Theory of Employment, Interest and Money, New York: Harcourt, Brace.

Kim, C.-J., C. Nelson, and J. Piger (2003), 'The less volatile US economy: a Bayesian investigation of timing breadth, and potential explanations,' Working Paper No 2001-016, St Louis, MO: Federal Reserve Bank of St. Louis.

Lavoie, M. (1992), Foundations of Post-Keynesian Economic Analysis, Aldershot, UK and Brookfield, VT: Edward Elgar.

Lucas, R.E. (1972), 'Expectations and the neutrality of money,' Journal of Economic Theory, $4(2), 102-124$

Lucas, R.E. (2003), 'Macroeconomic priorities,' American Economic Review, 93(1), 1-14.

Lutkepohl, H. (2011), 'Vector autoregressive models,' EUI Working Papers ECO 2011/30, European University Institute.

McConnell, M.M. and G. Perez-Quiros (2000), 'Output fluctuations in the United States: what has changed since the early 1980s?' American Economic Review, 90(5), 1464-1476.

Means, G.C. (1935), 'Price inflexibility and the requirements of a stabilizing monetary policy,' Journal of the American Statistical Association, 30(190), 401-413.

Meltzer, A.H (2005), 'Origins of the Great Inflation,' Review, Federal Reserve Bank of St. Louis, $87(2), 145-176$.

Meyer, L.H (2001), 'Does money matter?' Review, Federal Reserve Bank of St. Louis, 83(5), $1-16$.

Minsky, H.P. (1986), Stabilizing an Unstable Economy, New Haven, CT: Yale University Press.

$\mathrm{Ng}$, S. and P. Perron (1995), 'Unit root tests in ARMA models with data-dependent methods for the selection of the truncation lag,' Journal of the American Statistical Association, 90(429), 268-281.

Palley, T.I (2002), 'Economic contradictions coming home to roost? Does the US economy face a long-term aggregate demand generation problem?' Journal of Post Keynesian Economics, 25(1), 9-32.

Patterson, K. (2000), An Introduction to Applied Econometrics: A Time Series Approach, New York: Palgrave.

Romer, C. and D. Romer (2002), 'The evolution of economic understanding and postwar stabilization policy,' NBER Working Papers 9274, Cambridge, MA: National Bureau of Economic Research.

Sims, C. (1986), 'Are forecasting models usable for policy analysis?' Federal Reserve Bank of Minneapolis Quarterly Review, 10(1), 2-16. 
Smithin, J.N. (2003), Controversies in Monetary Economics, Cheltenham, UK and Northampton, MA: Edward Elgar.

Stock, J. and M.W. Watson (2003), 'Understanding changes in international business cycle dynamics,' NBER Working Papers 9859, Cambridge, MA: National Bureau of Economic Research.

Summers, P. (2005), 'What caused the Great Moderation? Some cross country evidence,' Economic Review, 3rd Quarter.

Sunkel, O. (1976), 'Inflation in Chile: an unorthodox approach,' International Economic Papers, 10, 107-131.

Taylor, J.B. (1979), 'Estimation and control of a macroeconomic model with rational expectations,' Econometrica: Journal of the Econometric Society, 47(5), 1267-1286.

Taylor, J.B. (1993), 'Discretion versus policy rules in practice,' Carnegie-Rochester Conference Series on Public Policy, 39(1), 195-214.

Taylor, J.B. (1999), 'A historical analysis of monetary policy rules,' in John B. Taylor (ed.), Monetary Policy Rules, Chicago: University of Chicago Press, pp. 319-348.

Taylor, J.B. (2012), First Principles: Five Keys to Restoring America's Prosperity, New York: W.W. Norton.

Taylor, L. (2004), Reconstructing Macroeconomics, Cambridge, MA: Harvard University Press.

Wicksell, K. (1898), Interest and Prices, London: Macmillan.

\section{APPENDIX A1 DATA SOURCES}

\section{Table A1 Data sources}

\begin{tabular}{|c|c|c|}
\hline Variable & Details & Source \\
\hline Federal Funds Rate & - & $\begin{array}{l}\text { Federal Reserve Bank of } \\
\text { St. Louis (FRED) }\end{array}$ \\
\hline Real GDP & - & $\begin{array}{l}\text { International Monetary Fund, } \\
\text { International Financial } \\
\text { Statistics (IMF IFS) }\end{array}$ \\
\hline CPI & Not seasonally adjusted & $\begin{array}{l}\text { Bureau of Labor Statistics } \\
\text { (BLS) }\end{array}$ \\
\hline Nominal oil prices & Spot price West Texas intermediate & FRED \\
\hline Nominal exchange rate & Weighted by largest trading partners & FRED \\
\hline Taylor rule differential & - & $\begin{array}{l}\text { Author calculated, raw data } \\
\text { from FRED }\end{array}$ \\
\hline Import prices & Not seasonally adjusted & IMF IFS \\
\hline Potential GDP & - & FRED \\
\hline GDP deflator & - & FRED \\
\hline Employment Cost Index & $\begin{array}{l}\text { Not seasonally adjusted, civilian } \\
\text { labor force, total compensation }\end{array}$ & $\begin{array}{l}\text { BLS: Employment Cost } \\
\text { Index, Historical Listing, } \\
\text { Volume V }\end{array}$ \\
\hline Unionization rate & Percentage of total employment & BLS \\
\hline $\begin{array}{l}\text { Michigan inflation } \\
\text { expectations }\end{array}$ & - & FRED \\
\hline $\begin{array}{l}\text { Personal Consumption } \\
\text { Expenditures Price } \\
\text { Index }\end{array}$ & - & FRED \\
\hline $\begin{array}{l}\text { Real hourly } \\
\text { compensation }\end{array}$ & $\begin{array}{l}\text { Used in Figure } 6 \text { because data for } \\
\text { Employment Cost Index only goes } \\
\text { back to } 1977 . \text { Non-farm, business } \\
\text { sector. }\end{array}$ & BLS \\
\hline
\end{tabular}




\section{APPENDIX A2 ALTERNATIVE ORDERING OF VAR}
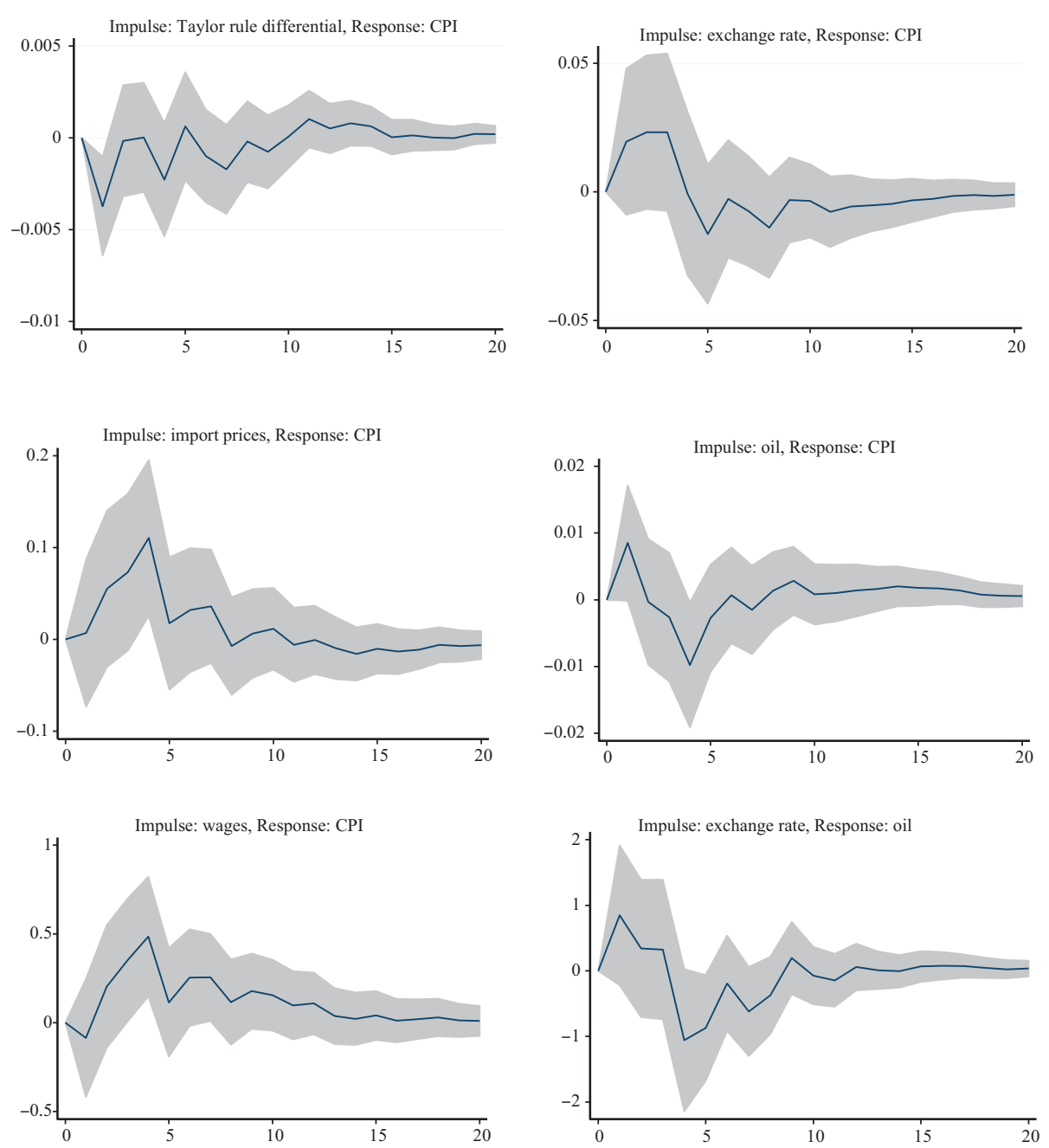

Figure A1 Impulse response functions for VAR order: import prices, exchange rate, oil, wages, CPI, and Taylor rule differential 

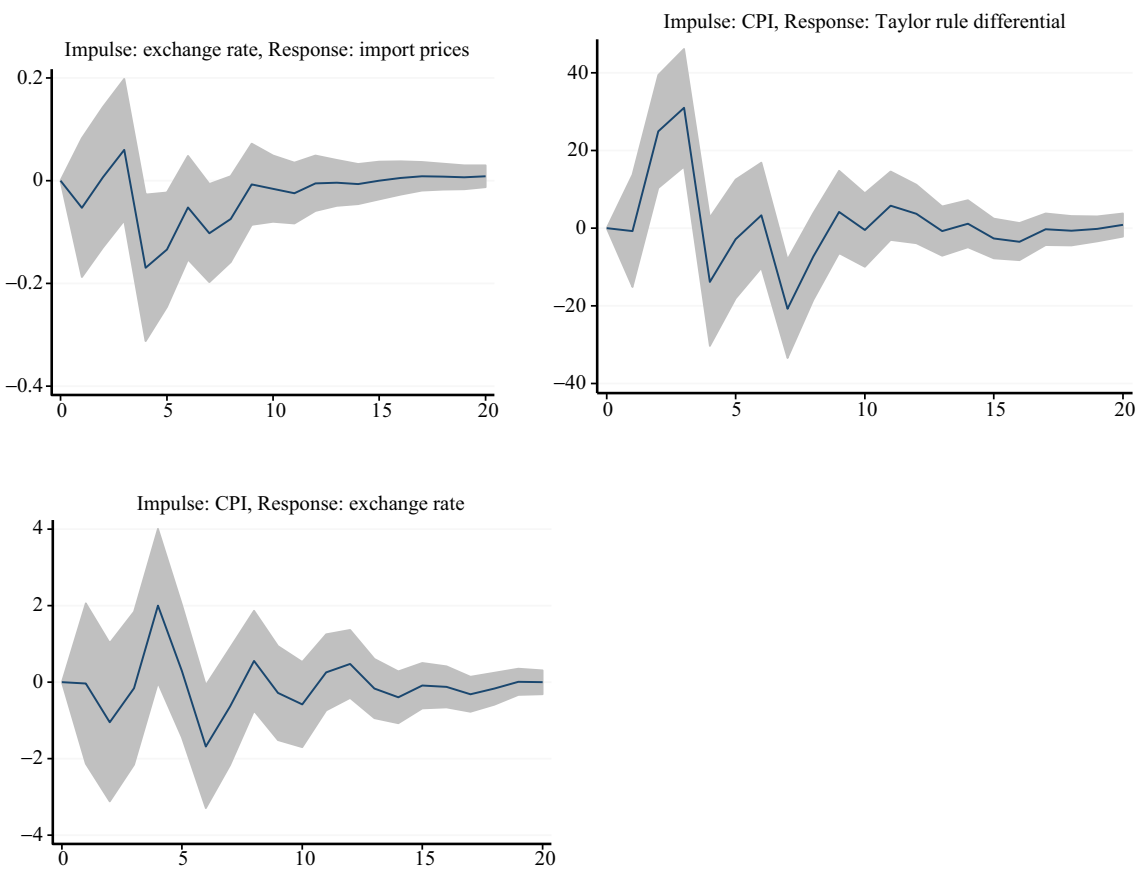

Figure Al (continued)

Table A2 Variance decomposition CPI

\begin{tabular}{|c|c|c|c|c|c|c|}
\hline $\begin{array}{c}\text { Variance decomposition } \\
\text { of the CPI (response) }\end{array}$ & & $\begin{array}{l}\text { Impulse } \\
\text { variable }\end{array}$ & & & & \\
\hline Horizon & CPI & Taylor rule & $\begin{array}{l}\text { Exchange } \\
\text { rate }\end{array}$ & $\begin{array}{c}\text { Import } \\
\text { prices }\end{array}$ & Oil prices & Wages \\
\hline 1 & 0.4048 & 0.0294 & 0.0355 & 0.5436 & 0.0001 & 0.0158 \\
\hline 2 & 0.3286 & 0.0274 & 0.0620 & 0.5264 & 0.0386 & 0.0147 \\
\hline 3 & 0.3555 & 0.0252 & 0.0674 & 0.4969 & 0.0359 & 0.0166 \\
\hline 4 & 0.3262 & 0.0306 & 0.0872 & 0.4846 & 0.0355 & 0.0410 \\
\hline 6 & 0.2846 & 0.0317 & 0.0861 & 0.4550 & 0.0596 & 0.0843 \\
\hline 10 & 0.2778 & 0.0353 & 0.0844 & 0.4444 & 0.0595 & 0.0956 \\
\hline 20 & 0.2747 & 0.0381 & 0.0859 & 0.4374 & 0.0627 & 0.1010 \\
\hline
\end{tabular}

\section{APPENDIX A3 VAR WITH TAYLOR RULE MODIFICATIONS}

Appendix A3 is an adjustment to the Taylor rule calculation in order to impose more realistic assumptions about the behavior of the Federal Reserve than what the original Taylor rule treatment provided. Note that in the body of the paper the intention is to 
test Taylor's original rule. This section develops a Taylor rule estimation that is more in line with how the Federal Reserve actually makes policy. In place of the GDP deflator, personal consumption expenditures (PCE) were used since this is the Fed's preferred measure of inflation. In addition to this, the Michigan inflation expectation measure is used in place of previous inflation expectations in order to provide a more forward-looking view of inflation expectations. Figure A2 and Table A3 illustrate the results of these changes, using the exact same model as used earlier in the paper. Ultimately, the results remain very similar. The most notable change is that the Taylor rule has a stronger impact on inflation, and is less ambiguous (and is in fact positive), and explains a higher percentage of variation (10 percent as opposed to 4 percent). Wages and import prices are still very important drivers of inflation in this model.
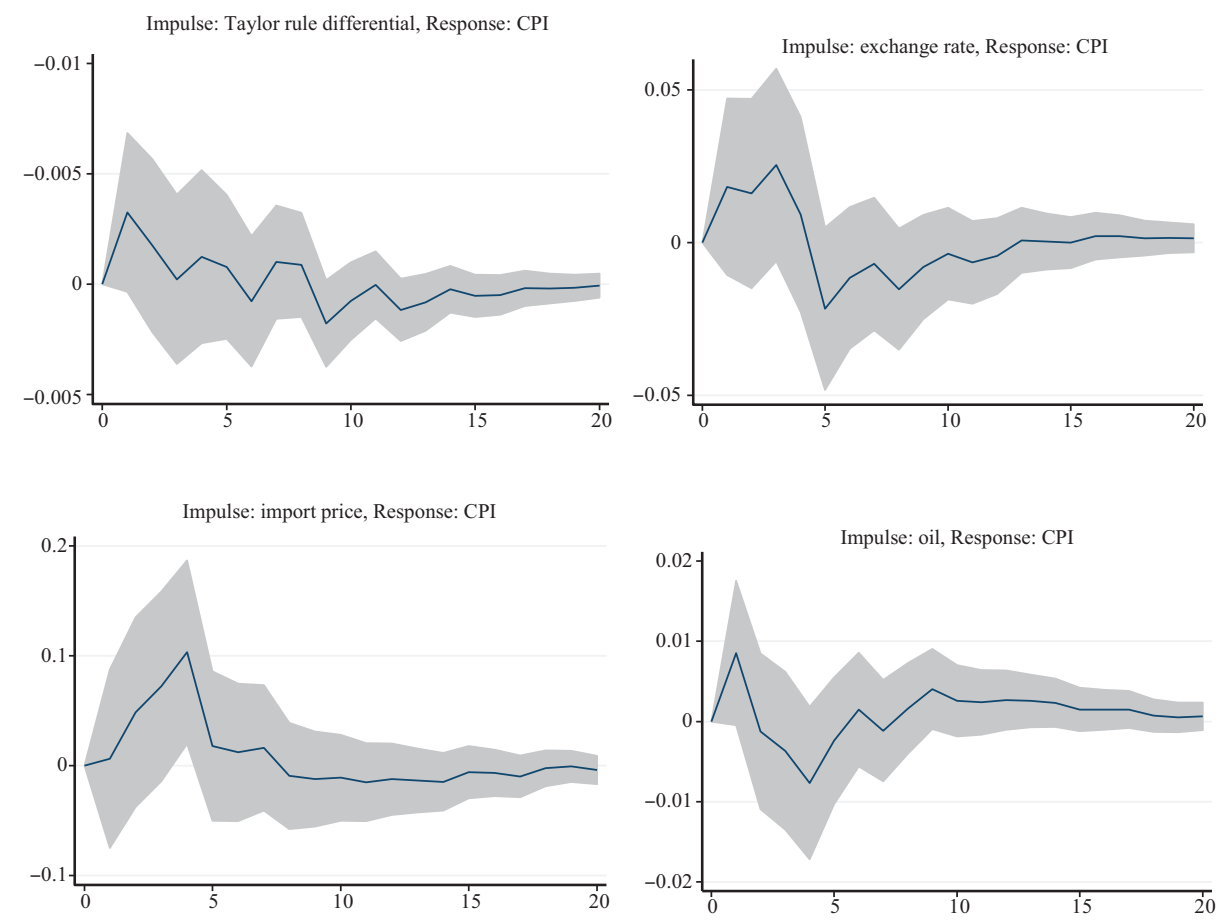

Figure A2 Impulse response functions with updated Taylor rule 
500 Review of Keynesian Economics, Vol. 4 No. 4
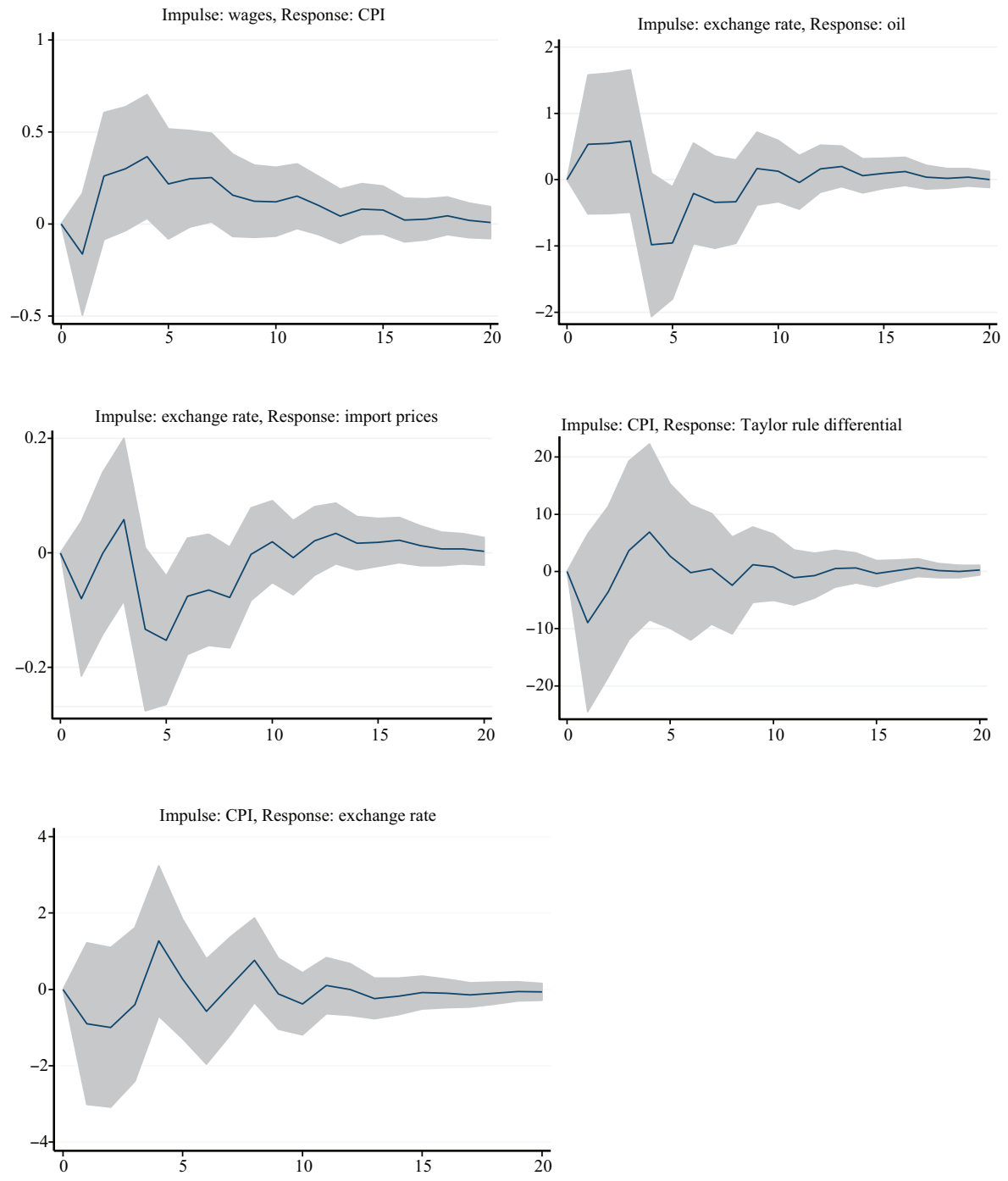

Figure A2 (continued) 
Table A3 Variance decomposition CPI using updated monetary policy rule

\begin{tabular}{lcccccc}
\hline $\begin{array}{l}\text { Variance decomposition } \\
\text { of the CPI (response) }\end{array}$ & \multicolumn{3}{c}{$\begin{array}{l}\text { Impulse } \\
\text { variable }\end{array}$} & & & \\
\hline Horizon & CPI & Taylor rule & $\begin{array}{c}\text { Exchange } \\
\text { rate }\end{array}$ & $\begin{array}{c}\text { Import } \\
\text { prices }\end{array}$ & Oil prices & Wages \\
\hline 1 & 0.4019 & 0.0548 & 0.0068 & 0.5171 & 0.0034 & 0.0156 \\
2 & 0.3272 & 0.1189 & 0.0080 & 0.4988 & 0.0293 & 0.0175 \\
3 & 0.3476 & 0.1125 & 0.0147 & 0.4729 & 0.0277 & 0.0243 \\
4 & 0.3208 & 0.1039 & 0.0227 & 0.4727 & 0.0311 & 0.0431 \\
6 & 0.2958 & 0.0967 & 0.0213 & 0.4534 & 0.0483 & 0.0717 \\
10 & 0.2735 & 0.0943 & 0.0471 & 0.4360 & 0.0515 & 0.0957 \\
20 & 0.2674 & 0.0972 & 0.0478 & 0.4239 & 0.0600 & 0.1033 \\
\hline
\end{tabular}

\section{APPENDIX A4 TESTS FOR AUTOCORRELATION AND NORMALITY IN THE PRIMARY MODEL}

\section{A4.1 Test for autocorrelation (models 1 and 2) ${ }^{18}$}

Table A4 indicates no autocorrelation, as none of the $p$-values are low enough to reject the null hypothesis.

\section{Table A4 LM test for autocorrelation}

\begin{tabular}{lc}
\hline Lag & $p$-value \\
\hline 1 & 0.3342 \\
2 & 0.2051 \\
3 & 0.3360 \\
4 & 0.8888 \\
\hline
\end{tabular}

Note: $* * *$ Indicates significance at the $99 \%$ level; $* *$ indicates significance at the $95 \%$ level; * indicates significance at the $90 \%$ level.

18. Note that the ordering of the VAR does not change the autocorrelation test results. 
502 Review of Keynesian Economics, Vol. 4 No. 4

\section{A4.2 Test for normality (model 1)}

Table A5 shows no evidence of skewness, but Table A6 illustrates evidence of kurtosis for 3 variables. Note that normality is not a necessary condition for vector autoregressions and impulse response functions (Lutkepohl 2011).

\section{Table A5 Skewness test}

\begin{tabular}{lc}
\hline Equation (in logged differences) & $p$-value \\
\hline 1 Taylor rule differential & 0.4755 \\
2 Exchange rate & 0.8769 \\
3 Import prices & 0.6595 \\
4 Oil & 0.3873 \\
5 Wages & 0.4069 \\
6 CPI & 0.5892
\end{tabular}

Note: $* * *$ Indicates significance at the $99 \%$ level; $* *$ indicates significance at the $95 \%$ level; * indicates significance at the $90 \%$ level.

Table A6 Kurtosis test

\begin{tabular}{lc}
\hline Equation (in logged differences) & $p$-value \\
\hline 1 Taylor rule differential & 0.0001 \\
2 Exchange rate & 0.4149 \\
3 Import prices & 0.7633 \\
4 Oil & 0.5764 \\
5 Wages & 0.7116 \\
6 CPI & 0.0006
\end{tabular}

Note: $* * *$ Indicates significance at the $99 \%$ level; $* *$ indicates significance at the $95 \%$ level; * indicates significance at the $90 \%$ level.

\section{A4.3 Test for autocorrelation (model 3 with updated Taylor rule differential)}

Table A7 indicates no autocorrelation, as none of the $p$-values are low enough to reject the null hypothesis.

\section{Table A7 LM test for autocorrelation}

\begin{tabular}{lc}
\hline Lag & $p$-value \\
\hline 1 & 0.1585 \\
2 & 0.1667 \\
3 & 0.1367 \\
& 0.3026 \\
\hline
\end{tabular}

Note: $* * *$ Indicates significance at the $99 \%$ level; $* *$ indicates significance at the $95 \%$ level; $*$ indicates significance at the $90 \%$ level. 